\title{
New species of the genus Cranichis (Orchidaceae, Cranichidinae) from Colombia
}

\author{
Dariusz L. Szlachetko • Marta Kolanowska
}

Received: 9 December 2012/ Accepted: 25 February 2013/Published online: 22 March 2013

(C) The Author(s) 2013. This article is published with open access at Springerlink.com

\begin{abstract}
Two new species of the Neotropical genus Cranichis are described: Cranichis carlos-parrae Szlach. \& Kolan. and Cranichis zarucchii Szlach. \& Kolan. Both species are known exclusively from the Colombian Andes, where they were found growing in montane forests and paramo above $2,550 \mathrm{~m}$ of elevation. Each species is described and illustrated, and the habitat and distribution data are provided. A distribution map of the new species is presented. A dichotomous key for identification Colombian species of Cranichis is provided.
\end{abstract}

Keywords Andes - Biodiversity - Cranichis .

New species $\cdot$ Paramo $\cdot$ Taxonomy

\section{Introduction}

The genus Cranichis was described by Olof Swartz in 1788 without designating the generitype, what was standard procedure at that time. The type species-C. muscosa Sw.-was selected over 150 years later (Acuña 1939). The taxonomic separateness of the genus is clear taking into consideration both morphological (Dressler 1993, Szlachetko and Rutkowski 2000) and molecular (Álvarez-Molina and Cameron 2009) studies. The only problematic species of Cranichis was $C$. fertilis (F. Lehm. and Kraenzl.) Schltr. which differs from other Cranichidinae by the triangular stigma, bifid rostellum and lack of hamulus (Garay and Romero-González 1999). Those morphological differences indicated the

D. L. Szlachetko · M. Kolanowska ( $\square)$

Department of Plant Taxonomy and Nature Conservation,

University of Gdańsk, UL. Wita Stwosza 59,

80-308 Gdańsk, Poland

e-mail: martakolanowska@wp.pl transfer of the species into a separate genus Exalaria Garay and G.A. Romero-Gonzalez. The creation of this monotypic genus was validated by the results of genetic research (Álvarez-Molina and Cameron 2009).

With the exclusion of Exalaria, Cranichis is easily distinguished from other cranichioid orchids by the villoushairy roots, the distinctly petiolate, suberect or arcuately spreading leaves, non-resupinate flowers, petals much narrower than sepals, and the fleshy, cochleate lip, often with conspicuously marked, coloured reticulate veins. The gynostemium is relatively massive, often swollen at the apex, without column-foot. The motile anther is oblong to ovate, two-chambered. The inconspicuous caudiculae are formed from the apices of pollinia. The clinandrium is usually thick, massive, spacious. The single viscidium is thick and relatively small and the hamulus is usually elongate, finger-like, thick, directed towards the anther (Szlachetko and Rutkowski 2000).

Species of Cranichis grows as terrestrial or lithophytic plants in lowlands as well as in montane forest, usually in humus and Sphagnum tussocks. Some populations were reported as subepiphytic. The altitudinal amplitude of the genus ranges from 350 up to 3,000 $\mathrm{m}$ a.s.l. (Carnevali and Ramírez-Morillo 2003; Cribb 2003).

Currently about 60 species distributed from Florida and Mexico to Bolivia and Argentina are included in Cranichis. In the Colombian orchid flora 19 species of the genus were found so far. Most of them, except C. muscosa and $C$. parvula, were reported from the submontane and montane regions of the country (Ortiz and Uribe 2007).

During the studies on Colombian Cranichidinae two distinctive species of the genus were found and are described here as new.

Cranichis carlos-parrae Szlach. \& Kolan. sp. nov. (Fig. 1). 


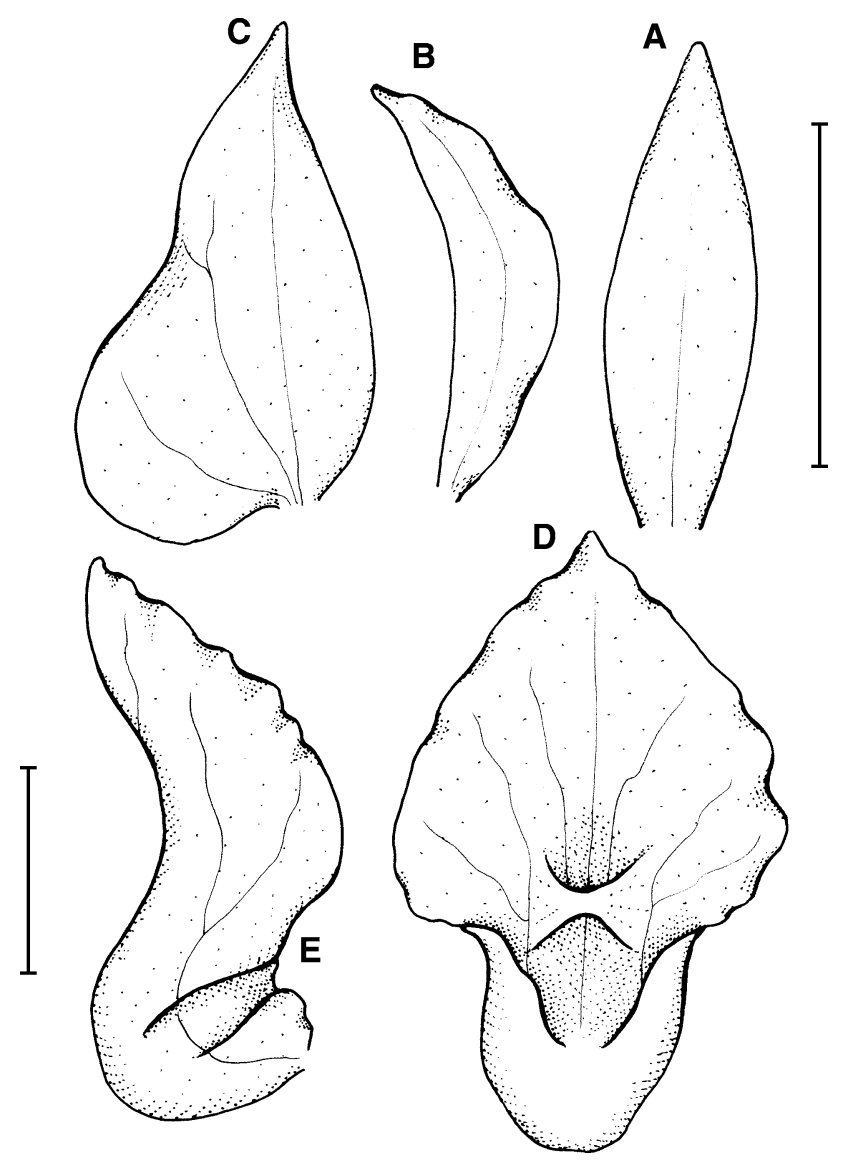

Fig. 1 Cranichis carlos-parrae Szlach. and Kolan. a dorsal sepal, b lateral sepal, c petal, d lip e lip (side view) Bars a-c $5 \mathrm{~mm}$, d-e $2 \mathrm{~mm}$ [Zarucchi, Brant and J. Castano 5694 (COL!); drawn by P. Baranow]

This species somewhat resembles C. gibbosa, but it is easily distinguishable from the latter and all other Colombian Cranichis by the form of lateral sepals which possess a prominent basal lobule, very narrow, glabrous petals and lip which is essentially bipartite with the upper part being broadly ovate-cordate, acute.

Type: C. Romero 88-Colombia, Cundinamarca, Parque Nacional Natural Páramo de Chingaza. Bosque de Encillo, alrededores de quebrada Malvinas, alt. 3,333 m (24 Sep 2000), (COL! 490311 holotype).

Plants to $20 \mathrm{~cm}$ tall. Leaves up to six, basal, rosulate, petiolate to sessile; petiole up to $1 \mathrm{~cm}$ long, narrow; blade up to $3.5 \mathrm{~cm}$ long and $1.2 \mathrm{~cm}$ wide, lanceolate, narrowly lanceolate to linear-lanceolate, acute. Scape erect, delicate, glandular in the upper part, enclothed in four sheaths. Inflorescence to $5 \mathrm{~cm}$ long, densely many-flowered. Flowers medium-sized, inconspicuous. Floral bracts to $13 \mathrm{~mm}$ long, lanceolate, acuminate, sparsely glandular. Pedicel and ovary up to $7 \mathrm{~mm}$ long, sparsely glandular. Sepals glabrous. Dorsal sepal $7 \mathrm{~mm}$ long, $2 \mathrm{~mm}$ wide, lanceolate, acute to subacute, 1-nerved. Petals $6 \mathrm{~mm}$ long,

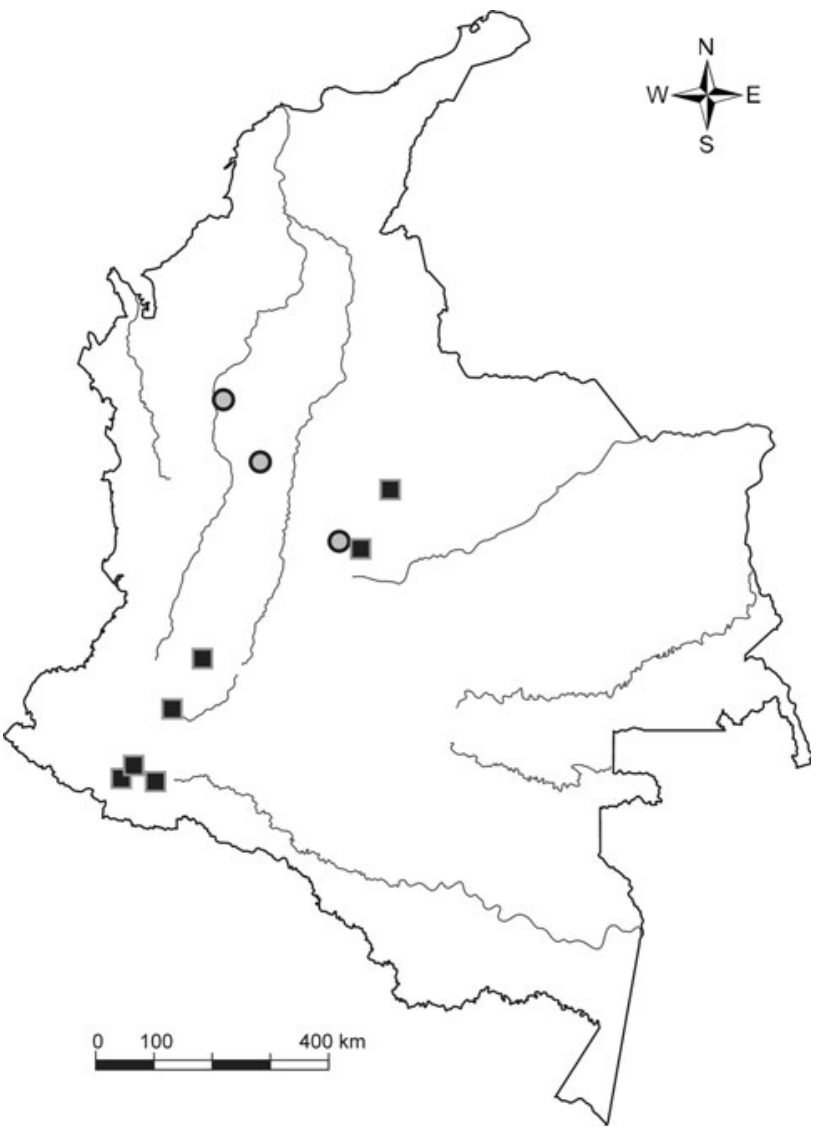

Fig. 2 Distribution of C. carlos-parrae (square) and C. zarucchii (circle) in Colombia

$1.3 \mathrm{~mm}$ wide, linear-lanceolate, acute, strongly falcate, glabrous along margins, 1-nerved. Lateral sepals $7.5 \mathrm{~mm}$ long, $5 \mathrm{~mm}$ wide, obliquely ovate, acute to shortly acuminate, somewhat oblique, basally expanded into auriculate lobule, 3-nerved. Lip bipartite; basal part $2 \mathrm{~mm}$ long, $1.5 \mathrm{~mm}$ wide, sessile, saccate, somewhat compressed laterally; apical part $4 \mathrm{~mm}$ long and wide, cordate-ovate in outline, acute, margins somewhat wavy. Gynostemium $3.8 \mathrm{~mm}$ long.

Etymology: Dedicated to the Curator of Colombian National Herbarium (COL) in Bogotá, Dr Carlos Parra.

Ecology: This species was found in the paramo and subparamo, often near the small lakes. Some populations were reported from dwarf forest. Alt. 2,550-3,350 m.

Distribution: So far this species is known only from the Colombian Central and Eastern Cordilleras Fig. 2.

Other representative specimens: G. Huertas and L.A. Camargo 6250-Colombia, Boyacá, Mpio. de Ramiriqui. Cordillera Oriental. Camino hacia la Laguna Negra. Planta aquatica, alt. 2,580 m (12 Oct 1965), (COL!); O. Rangel 2497-Colombia, Cauca, Las Flautas. Carretera ToezTacueyo, km 45-46, alt. 3,180 m (10 Sep 1980), (COL!); Idrobo, Pinto \& Bischler 3897-Colombia, Cauca, Macizo 
Colombiano. Alrededores de la laguna de Cusiyaco. Bosques, alt. 3,200 m (7-12 Oct 1958), (COL!); C. Romero 80-Colombia, Cundinamarca, Parque Nacional Natural Páramo de Chingaza. Costado izquierda de la carretera que del Embalse del Chuza conduce al campamento Monteredondo, alt. 3,010 m (20 Sep 2000), (COL!); Schneider 544-Colombia, Cundinamarca, Gachancipe, alt. 2,600 m (1 Jan 1951), (COL!); Knoth 3325-Colombia, Nariño, Carretera del Norte, km 7, alt. 3,000 m (20 Jul 1951), (COL!); Knoth 3335-Colombia, Nariño, Carretera Sur. Region Yacuanquer, alt. 2,900-3,000 m (29 Apr 1951), (COL!); Cuatrecasas 11957-Colombia, Nariño, Entre El Encano y Pasto, vertiente occidental de la Cordillera. Bosque residuals entre Páramo del Tábano y Laguna, alt. 2,700-2,900 m (11 Jan 1941), (COL!); M.B. and R. FosterColombia, Putumayo. Tabanel, above La Cocha. Paramo cloud forest, alt. 3,300 m (31 Oct 1946), (COL!).

Taxonomic notes: This species can be distinguished from Colombian members of the genus Cranichis by having very narrow dorsal sepal and petals, lateral sepals with expanded basal outer margin forming a kind of lobe and peculiar lip morphology. Lip is bipartite; its basal part is saccate, laterally compressed and apical part is spread, somewhat conduplicate, ovate-cordate with acute apex.

Cranichis zarucchii Szlach. \& Kolan. sp. nov. (Fig. 3).

Species similar to C. engelii, but dorsal sepal 3-nerved, petals with marginal ciliae shorter than half width of petals and lip margins somewhat wavy at the base only. It differs from closely related $C$. cylindrostachys by nervation of sepals, form of petals and proportion in lip lenght versus width.

Type: Zarucchi, Brant and J. Castano 5694-Colombia, Antioquia, Mpio. Frontino. Km 12 of road Nutibara-Murri. Disturbed wet/very wet montane vegetation, roadside, $6^{\circ} 45^{\prime} \mathrm{N}, 76^{\circ} 22^{\prime} \mathrm{W}$, alt. 2,010 m (23 Sep 1987), (COL! 317493 holotype).

Plants to $50 \mathrm{~cm}$ tall. Leaves 1-2, basal, petiolate; petiole to $11 \mathrm{~cm}$ long, narrow; blade up to $9 \mathrm{~cm}$ long and $2.5 \mathrm{~cm}$ wide, triangular-ovate, acute. Scape erect, delicate, glabrous in the lower half, densely glandular below and within inflorescence, enclothed distantly in 3-5 sheaths. Inflorescence to $12 \mathrm{~cm}$ long, many-flowered. Flowers small, inconspicuous. Floral bracts $5 \mathrm{~mm}$ long, lanceolate, acuminate, glabrous. Subsessile ovary up to $9 \mathrm{~mm}$ long, densely and very minutely papillate. Sepals glabrous. Dorsal sepal $4.2 \mathrm{~mm}$ long, $2.1 \mathrm{~mm}$ wide, oblong-ovate, subobtuse, somewhat cochleate in the centre, obscurely 3-nerved. Petals $4 \mathrm{~mm}$ long, $0.9 \mathrm{~mm}$ wide, oblong- or linear-lanceolate, subacute to subobtuse, falcate, densely and softly ciliate along both margins except base and apex, 1-nerved. Lateral sepals $4.2 \mathrm{~mm}$ long, $2.1 \mathrm{~mm}$ wide, obliquely ovate to elliptic-ovate, somewhat acuminate, acute to subacute,
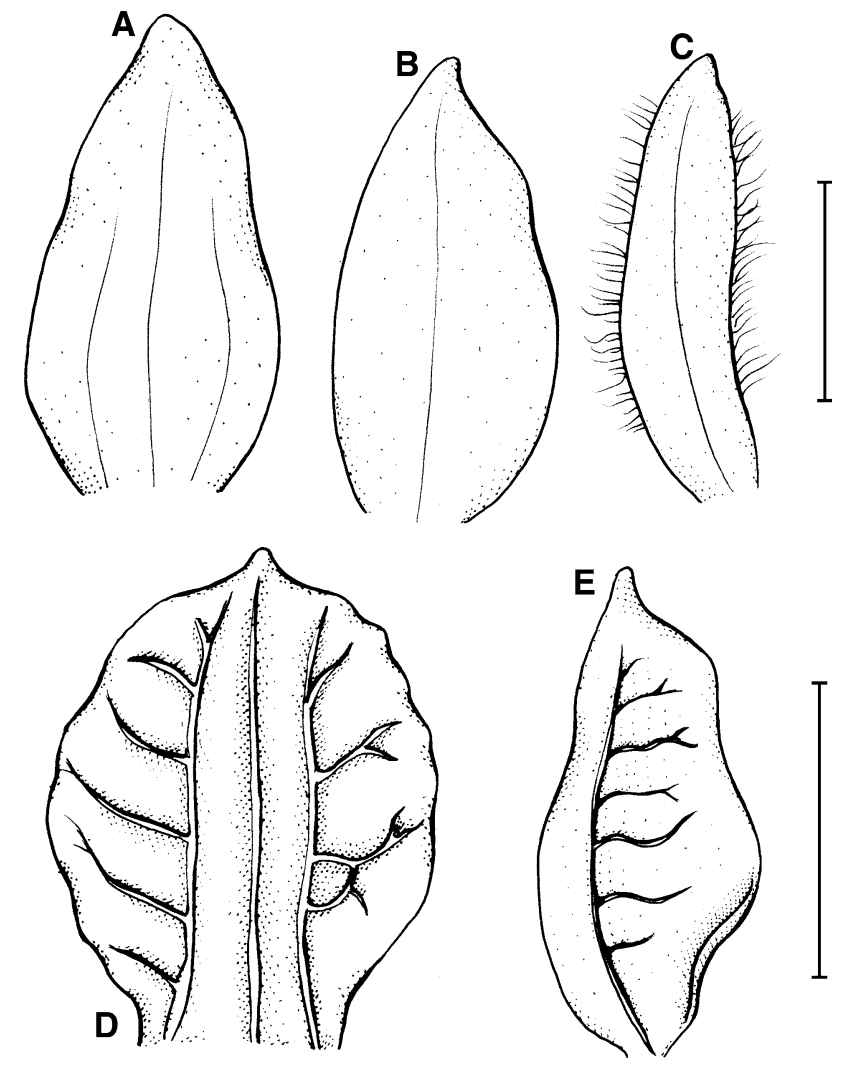

Fig. 3 Cranichis zarucchii Szlach. and Kolan. a dorsal sepal, b lateral sepal, c petal, d lip e lip (side view) Bars: $2 \mathrm{~mm}$. C. Romero 88-Colombia (COL!); drawn by P. Baranow]

slightly concave, 1-nerved. Lip $3.5 \mathrm{~mm}$ long, $2.7 \mathrm{~mm}$ wide, elliptic-ovate in outline, widest just below the middle, apex truncate with short, triangular, acute apiculus, margins somewhat wavy at base, lamina shallowly cochleate below the centre, nerves three, protruding, profusely branching, sometimes secondarily branches can be observed. Gynostemium $2 \mathrm{~mm}$ long.

Etymology: Dedicated to James Zarucchi, the co-collector of the type specimen of this species.

Ecology: This species grows in a pluvial subparamo as well as in the wet and very wet montane areas. Alt. 2,700-2,800 m a.s.l.

Distribution: So far this species is known only from the Colombian Andes Fig. 2.

Other representative specimens: Zarucchi, Betancur and F.J. Roldan 5177-Colombia, Antioquia, Mpio. Sonsón, Km 11 of road Sonsón-Nariño. $25 \mathrm{~km}$ from Narino, near km post 151 marking distance from Bogotá. Pluvial subparamo vegetation. $5^{\circ} 42^{\prime} \mathrm{N}, 75^{\circ} 15^{\prime} \mathrm{W}$, alt. $2,780 \mathrm{~m}$ (1 Apr 1987), (COL!); G. Lozano C. and J. Rivera 2211-Colombia, Antioquia, Mpio. Sonsón, Sobre la carretera hacia Nariño. Alt. $2740 \mathrm{~m}$ (5 May 1972), (COL!); Schneider 11/1 p.p.-Colombia, Cundinamarca, Alrededores de Bogotá. 

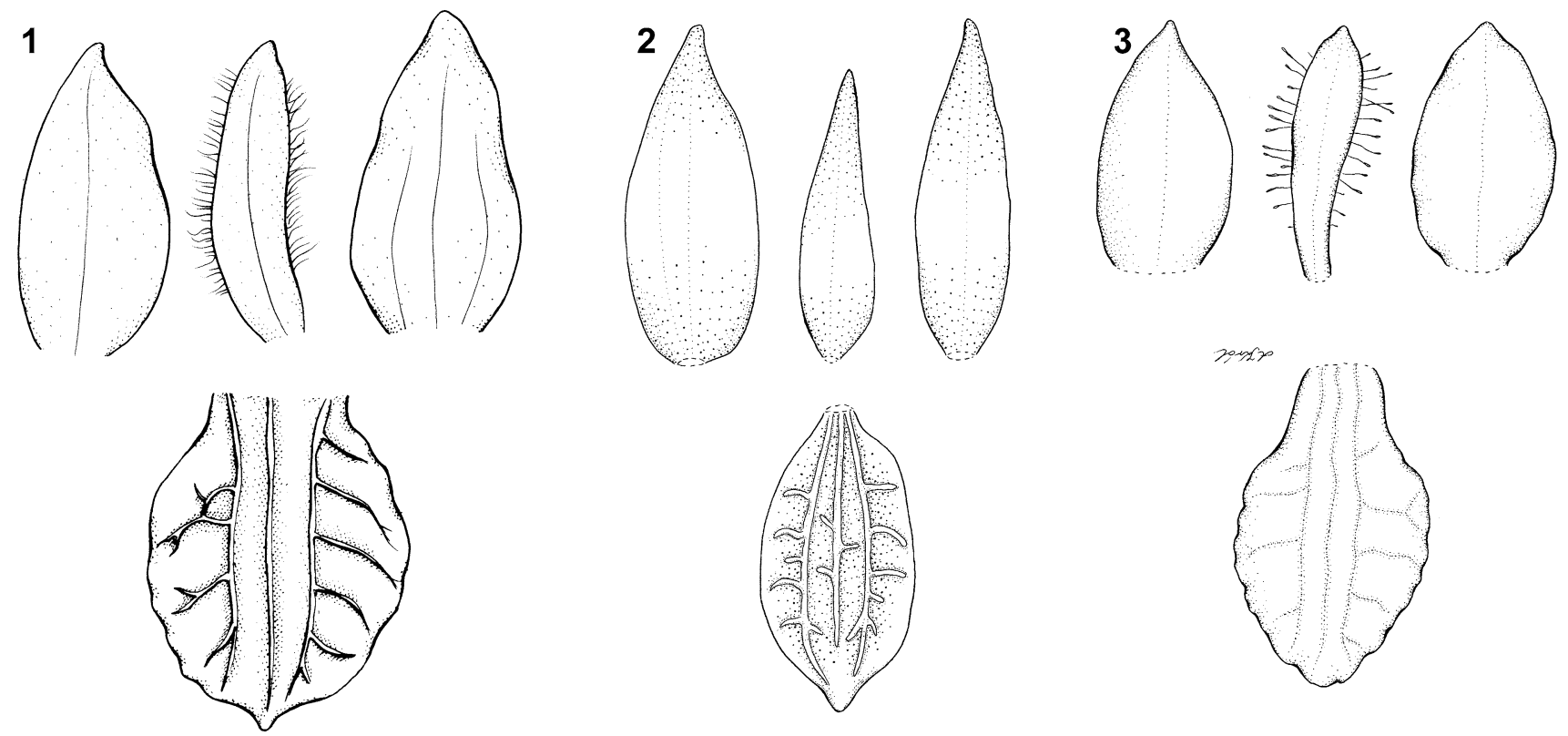

Fig. 4 Comparison of the dissected perianths of Cranichis zarucchii (1), C. cylindrostachys (2) and C. engelii (3) [drawn by P. Baranow and A. Król]

Quebrada de El Chico, alt. 2,700-2800 m (18 May 1944), (COL!).

Taxonomic notes: $C$. zarucchii appears to be similar to both $C$. engelii Rchb.f. and C. cylindrostachys Schltr. It is easily separable from the former by having 3-nerved dorsal sepal (vs. 1-nerved), petals with marginal ciliae shorter than half width of petals (vs.ciliae almost as long as width of petals) and lip margins somewhat wavy at the base only (vs.lip margins prominently wavy). In addition, $C$. zarucchii differs from $C$. engelii by the densely glandular scape (vs.scape glabrous) and the subsessile lip (vs.lip clawed). The lateral sepals are widest below the middle (vs.widest near the middle in $C$. engelii) and the petals are widest near the middle (vs.widest below the apex in C. engelii). Unlike C. zarucchii, C. cylindrostachys has 1-nerved dorsal sepal, obscurely 2-nerved lateral sepals, petals linear-lanceolate with glabrous margins and oblong-elliptic lip (Fig. 4).

Key to the Colombian species of Cranichis.

1 Petals with long hairs (threadlike, multi-cellular outgrowths from the epidermis) along the margins ........ C. wageneri

$1^{*}$ Petals without long hairs on the margins 2

2 Petals ciliate (with a hair-like glandular projections of the cell surface) ..... 3

$2 *$ Petals with entire or slightly erose margins, glabrous ...... 13

3 Scape glabrous 4

3* Scape glandular or glandular-pubescent 7
4 Lip ovate-elliptic C. crumenifera

4* Lip ovate to suborbicular 5

5 Petals from a short claw broadly oblanceolate to elliptic .... C. polyantha

$5^{*}$ Petals linear-ligulate to oblong-oblanceolate ...... 6

6 Lip midvein unbranched C. engelii

6* All lip veins branching

C. muscosa

7 Ovary glandular or papillate 8

$7 *$ Ovary glabrous ....... 10

8 Lip without any additional projections on the surface ...... 9

$8^{*}$ Lip with spiculate pustules or knob-like projections ....... C. schlimii

9 Lateral sepals obscurely 3-veined, lip obtuse at the apex C. brachyblephara

9* Lateral sepals obscurely 1 -veined, lip truncate at the apex with short, triangular, acute apiculus ..... $C$. zarucchii

10 Inflorescence elongate, raceme $8-12 \mathrm{~cm}$ long, longer than the leaf blade ....... C. antioquiensis

$10^{*}$ Raceme up to 5-7 $\mathrm{cm}$ long, shorter than the leaf blade 11

11 Ovary about 5-6 $\mathrm{mm}$ long, flowers about $3 \mathrm{~mm}$ in diameter ....... 12

11* Flowers about $3.5 \mathrm{~mm}$ in diameter, ovary up to 11 $\mathrm{mm}$ long C. ciliata

12 Sepals attenuate towards apex, petals minutely ciliate along margins, lip longer than wide

C. pleioneura 
12* Sepals rounded at apex, petals pubescent along margins, lip as long as wide C. polyblephara

13 Petals margins erose C. picta

13* Petals margins entire 14

14 Leaves narrowly oblanceolate to lanceolate 15

14* Leaves ovate, ovate-lanceolate to orbicular 16

15 Lateral sepals obliquely oblong-triangular, outer margin not forming a lobe

C. lehmanniana

$15^{*}$ Lateral sepals obliquely ovate with expanded basal outer margin forming a kind of lobe ...... C. carlosparrae

16 Leaves usually two, often one of them is much larger than another C. diphylla

16* Leaves several, subequal in size 17

17 Petals elliptic C. gibbosa

17* Petals lanceolate to oblong-oblanceolate 18

18 Floral bracts subequal or longer than ovary . $C$.

lehmannii

18* Floral bracts shorter than ovary 19

19 Leaf blade elliptic to orbicular; petiole $0.4 \mathrm{~cm}$ long; blade $0.9-6 \times 0.6-2 \mathrm{~cm}$ C. tenuis

19* Leaf blade broadly ovate to broadly elliptic; petiole at least $1 \mathrm{~cm}$ long; blade $4-8 \times 2-4 \mathrm{~cm}$ 20

20 Petiole up to $2.5 \mathrm{~cm}$ long, lip unlobed........ $C$. parvula

20* Petiole up to $9 \mathrm{~cm}$ long, lip 3-lobed at apex ..........

C. pulvinifera

Acknowledgments The curator and staff of the herbarium COL are thanked for their kind hospitality and assistance during visits and for making specimens available on loan. We are grateful to Przemysław Baranow and Anna Król for preparing the illustrations. The research described here has been supported by the Polish Ministry of Science and Higher Education (research grant no. 8124/B/PO1/2011/40).

Open Access This article is distributed under the terms of the Creative Commons Attribution License which permits any use, distribution, and reproduction in any medium, provided the original author(s) and the source are credited.

\section{References}

Acuña J (1939) Catalogo descriptivo de las Orquideas Cubanas. Bol Ticn Estac Exp Agron 60:48

Álvarez-Molina A, Cameron KM (2009) Molecular phylogenetics of Prescottiinae s.l and their close allies (Orchidaceae, Cranichideae) inferred from plastid and nuclear ribosomal DNA sequences. Am J Bot 96:1020-1040

Carnevali G, Ramírez-Morillo IM (2003) Cranichis. In: Steyermark JE, Berry PE, Yatskievych K, Holst BK (eds) Flora of the venezuelan guayana, vol 7. Missouri Botanical Garden Press, St. Louis, Myrtaceae-Plumbaginaceae

Cribb P (2003) Cranichis. In: Pridgeon AM, Cribb PJ, Chase MW, Rasmussen FN (eds) Genera Orchidacearum, vol 3. Oxford University Press, USA, p 33

Dressler RL (1993) Phylogeny and classification of the orchid family. Dioscorides Press, Portland

Garay LA, Romero-González G (1999) Schedulae orchidium II. Harv Pap Bot 4:475-488

Ortiz VP, Uribe VC (2007) Galería de orquídeas de Colombia (CD edition). Asociación Bogotana de Orquideología, Bogotá

Swartz O (1788) Nova genera and species plantarum: seu, prodromus descriptionum vegetabilium, maximam partem incognitorum qua sub itinere in indiam occidentalem annis 1783-1787. Nabu Press, USA

Szlachetko DL, Rutkowski P (2000) Gynostemia orchidalium:volume 1. apostasiaceae, cypripediaceae, orchidaceae (thelymitroideae to vanilloideae). Acta Bot Fen 169:295-296 